\title{
JOB SATISFACTION OF MANAGERS IN COOPERATIVES OF POKHARA
}

\author{
Dhaneshwar Rakhal*
}

\begin{abstract}
This study tires to measure the job satisfaction level of managers working in saving and credit cooperative societies in Pokhara. It specially, ranks the managers' feelings about the general factors related to job satisfaction. It also considers gender, work experience and remuneration in relation to job satisfaction. It is based on the primary source of information and data collected through structured questionnaire. The data cover managers (office head) of 77 saving and credit cooperatives in Pokhara. Percentage, mean score, median, rank and chi-square test were used as analytical tools. The result of the study indicates that the five of the nine job satisfaction factors were under the satisfaction level. The result also points out that the female were more dissatisfied than male, and there was negative association between job experience and overall job satisfaction level and positive association between remuneration and overall job satisfaction.
\end{abstract}

Key words: Cooperatives, job satisfaction, factors of job satisfaction, manager.

\section{INTRODUCTION AND OBJECTIVE}

Employees' role is an essential part for the organizational success and competitiveness. The employees have different viewpoints about their career, jobs, and their organizations, and job satisfaction is the most central (Saari \& Judge, 2004). The feeling regarding their job may be positive or negative. According to Robbins, Judge, and Vohra (2013), job satisfaction is "a positive about a job" (p. 83). Similarly, for Moorhead and Griffin (2000), it is "an individual's attitude toward her or his job" (p. 112). So, employees may have their distinctive feelings and about their jobs. So, job satisfaction is directly related to the positive and favorable attitude towards their Job and dissatisfaction comes out of their negative attitude. Job satisfaction is also a positive emotional state of employees' experiences (Shrestha, 2015). It has many dimensions. According to Luthan (as cited in Tella, Ayeni \& Popoola, 2007), there are three dimensions relating to job

* Mr. Rakhal is a Teaching Assistant, Prithivi Narayan Campus, Pokhara, TU. 
satisfaction i.e., emotional response, expectancy and attitudes. The "pay, opportunities for promotion, the nature of the job itself, the organization's policies and procedures, and working conditions usually determines the job satisfaction or dissatisfaction" (Moorhead, Griffin, 2000, p. 113). The social context of job, place and overall job satisfaction are also inter-related. Job characteristics that contribute to training, feedback, variety, independence, social recognition, control, and interaction with co-worker provide motivation for satisfaction (Atreya, 2014; Robbins, Judge, \& Vohra, 2013). So, job satisfaction may be influence by different factors.

Job satisfaction or dissatisfaction directly affects employees' turnover and absenteeism. Dissatisfied employees more often become absent from their job reporting their sickness even when they are healthy. They tend to move to a new organization for attractive job. Conversely, when employees are satisfied, they come to work more regularly and are less likely to seek other employments (Moorhead \& Griffin, 2000). It also applies in case of cooperative managers. Therefore, highly satisfied cooperative managers feel positive towards their job, while manager with low level of job satisfaction hold negative feelings. Consequently managers' job satisfaction affects on organizational productivity and performance.

The purpose of this study is to find out the job satisfaction of Managers in cooperative of Pokhara however research questions raised in the paper include: (a) What is the perception of managers on their job satisfaction level in relation to the factors related to job satisfaction? (b) What is the status of overall job satisfaction level? (c) What is the relation of gender, work experience and remuneration with the job satisfaction?

\section{REVIEW OF LITERATURE}

Tella, Ayeni and Popoola (2007) have written a research paper relating to employees' work motivation, job satisfaction and organizational commitment. The findings of the paper show a positive correlation of job satisfaction with motivation and commitment, but negative correlation between motivation and commitment. There was no difference between perceived motivation of professional and non-professional library employees. The findings of the paper also show some salient issues in the field of librarianship. The paper suggests that the management should meet the demands of their employees to promote their motivation, satisfaction, and commitment and minimize their turnover. The study of Yousef (2000) has also analyzed the relationship of leadership behavior with 
organizational commitment, job satisfaction and job performance of the employees. It suggests that the management should accept any important activities to improve the satisfaction level of the employees. They highlight about management activities and national cultural influences on job satisfaction. The study hints that for the improvement of the job satisfaction and performance, the organization requires a suitable leadership of the manager. Chadi and Hetschko (2014) have investigated a crucial event for job satisfaction: changing the workplace. The result indicates the linkage between the new job and satisfaction level of employees. When an employee starts a new job, on average, he/she gets very high job satisfaction, but the satisfaction gradually declines over the passage of time. Similarly, the huge new job options results the majority of the voluntary job changes of the employees. Saari and Judge (2004) have highlighted on employees' attitude, basically in terms of three areas of job satisfaction. Which include attitude of the employees, the outcome of positive or negative job satisfaction, and the ways to assess and influence attitude of the employees. The paper identifies the major practitioners' knowledge gaps in these areas, and suggests for the practitioners to fill the gaps. The relation of job satisfaction and job performance, job satisfaction and life satisfaction, and job satisfaction and withdrawal behaviors have been indicated in this paper.

Sukriket (2018) found a significant correlation between many of the job facts and turnover intention using four variables: supervision, remuneration, work environment and job condition concerned with the software programmers' job turnover plan. This implies that human resource management (HR) in the information technology (IT) industry in Thailand need to pay special attention to these factors in order to retain their skilled IT employees. The result indicates that 44.8 percent of employees were willing to continue their current job for three years but 41 percent were undecided to see their current job over the same period. The younger respondents, who had worked for only 1-2 years, were strongly interested to shift into another company. Sukriket suggests that favorable strategies for IT professionals should be introduced in business sector for the reduction of turnover. The researcher also suggests that the high turnover could be reduced by findings root causes, addressing the problem and implementing the strategies in IT sectors. Similarly, Grund and Rubin (2016) have done a study on "social comparison of wage increase and job satisfaction". The researchers used a panel data set of managers in the German chemical industry. They compare the status quo and social comparison considerations. They investigate 
the relationship between wages increase of individual employees and comparable employees; and its impact on related manager's job satisfaction. The result shows, an increase of relative wages - even absolute wage level is same - decreases the individual managers' job satisfaction. Based on the findings from the about literature review, it is clear that different researchers have studied on job satisfaction of employees in different ways. These studies are mainly based on the relationships of job satisfaction with work motivation, organizational commitment, leadership behavior, job performance, new job, withdrawal behaviors, work environment and job condition of the employees in library and different business organization and have been forwarded in different nations and communities under different circumstances. But, this study is different as it tries to study the relationships of job satisfaction with different "job satisfaction factors" in relation to the managers of the saving and credit cooperatives in Pokhara. It also compares the job satisfaction in terms of gender, experience and remuneration of the managers of cooperatives in Nepalese context. Therefore, the study is of its own kind and measures the job satisfaction level of managers working in saving and credit cooperatives societies in Pokhara.

\section{METHODOLOGY}

For the study purpose, the required information was collected on existing phenomenon. In mid July 2015, there were 212 saving and credit cooperative societies in Pokhara Sub-metropolitan (Cooperative Training and Division Office, 2015), Kaski, Nepal. Out of these 212 cooperatives, 77 cooperatives were selected as the sample of the study. Seventy seven managers (Office Head) - from the each one representing the sample cooperatives-were the sample respondents. Convenience sampling method was used for the study. Copies of structured questionnaire were prepared as the instruments for the data collection. The questionnaire was translated into Nepali to make it easier for the respondents. The questionnaire was divided into two parts. The first part dealt with the profile and the managerial characteristics of the respondents, and the second part was about the factors of job satisfaction, what the managers feel in their real life. The questions about the job satisfaction factors were based on Minnesota satisfaction questionnaire (Welss, Dawis, England \& Lofquist, 1967) using five-point Likert scale (Likert, 1932). The respondents were contacted for questionnaire survey in their offices of cooperatives. The time for the respondents was set considering their convenience and the questionnaire were filled up and collected. All the data collected through 
questionnaire were processed using SPSS software. The responses frequencies were categorized, and frequencies, percentages, mean value and rank were computed and interpreted. Mean score was also used for the comparison of variables as used in previous studies i.e. Pradhan (2003) and Pravin and Kabir (2011). Besides, regression analysis is also used wherever applicable.

\section{DISCUSSION AND RESULT}

\section{Socio-Demography of Respondents}

Questionnaire was developed to obtain general information related to sample cooperatives and their managers. It consists of sex, age, marital status, caste/ethnicity, and monthly salary of the managers. Age distribution of the respondent managers is given in Table 1. About 36.4 percent of the managers are of below 30 in age, 29.9 percent are of 30 to 40 years, 20.8 percent are of 40 to 50 years and the rest are of 50 years and above. The average age of the managers is 35.65 years. As evident form Table 1, 76.6 percent of cooperative managers are married and the rest, 33.4 percent, are unmarried. It indicates the dominancy of married managers in saving and credit cooperatives in Pokhara. About the religion of the cooperative managers, 90.9 percent managers are Hindu and 9.1 percent are Buddhist. Likewise, the Table shows that 77.9 percent of the respondent managers are from Brahmin/Chhetry, 15.6 percent from Janajati, 3.9 percent from Dalit community and 2.6 percent from other, i.e., Dasnami and Ghale. Janajati includes Gurung, Magar, Newar, Tamang in this study.

Most of the financial practitioners hold bachelor or higher degree. The Table shows, 48.1 percent of the managers are holding bachelor's degree, 28.6 percent and 18.2 percent are holding master's degree and higher secondary degree respectively. Similarly 3.9 percent and 1.3 percent are holding secondary and under secondary level respectively. As was expected, Table 1 also indicates that most (67.5 percent) of the managers hold degree from management stream, 18.2 percent from social sciences and 3.9 percent from education stream. Rest of the other ( 7.8 percent) includes degree in English literature, science, and without specialization (secondary and under secondary level). As it is indicated by Table 1, the majority of the respondents - i.e. 64.9 percent - hold the position of manager but there is also a good number holding the position of chief executive. It includes chief executive officer, executive chief, executive director, general manager and managing director. covering 23.4 percent, whereas 5.2 percent 


\section{JOB SATISFACTION OF MANAGERS IN COOPERATIVES OF POKHARA}

as accountant, 3.9 percent as office assistant, and 2.6 percent hold other designation (Table 1).

Table 1: Socio-demographic Profile of Respondents $(n=77)$

\begin{tabular}{|c|c|c|c|c|c|}
\hline Description/Criteria & \multirow{2}{*}{ Number } & \multirow{2}{*}{ Percent } & \multirow{2}{*}{\begin{tabular}{|l|} 
Description/Criteria \\
Area of Specialization
\end{tabular}} & \multirow{2}{*}{ Number } & \multirow{2}{*}{ Percent } \\
\hline Gender & & & & & \\
\hline Male & 60 & 77.9 & Management & 52 & 67.5 \\
\hline Female & 17 & 22.1 & Law & 2 & 2.6 \\
\hline Age & & & Social Science & 14 & 18.2 \\
\hline Below 30 Years & 28 & 36.4 & Education & 3 & 3.9 \\
\hline $30-40$ & 23 & 29.8 & Other & 6 & 7.8 \\
\hline $40-50$ & 16 & 20.8 & Job Experiences & & \\
\hline 50 and Above & 10 & 13.0 & Below 1 year & 6 & 7.8 \\
\hline Marital Status & & & $1-5$ & 33 & 42.8 \\
\hline Married & 59 & 76.6 & $5-10$ & 29 & 37.7 \\
\hline Unmarried & 18 & 23.4 & $10-15$ & 4 & 5.2 \\
\hline Caste/Ethnicity & & & 15 and Above & 5 & 6.5 \\
\hline Brahmin/Chhetri & 60 & 77.9 & Designation & & \\
\hline Janajati & 12 & 15.6 & Chief Executive & 18 & 23.4 \\
\hline Utpidit (Dalit) & 3 & 3.9 & Manager & 50 & 64.9 \\
\hline Other & 2 & 2.6 & Assistant Manager & 2 & 2.6 \\
\hline Religion & & & Accountant & 4 & 5.2 \\
\hline Hindu & 70 & 90.9 & Office Assistant & 3 & 3.9 \\
\hline Buddhist & 7 & 9.1 & $\begin{array}{l}\text { Monthly } \\
\text { Remuneration }\end{array}$ & & \\
\hline \begin{tabular}{|l|} 
Education Level \\
\end{tabular} & & & Below Rs. 10000 & 14 & 18.2 \\
\hline Below Secondary & 1 & 1.3 & $10000-20000$ & 14 & 18.2 \\
\hline \begin{tabular}{|l|} 
Secondary Level \\
\end{tabular} & 3 & 3.9 & 20000-30000 & 30 & 38.9 \\
\hline Higher Secondary & 14 & 18.2 & $30000-40000$ & 12 & 15.6 \\
\hline Bachelor Level & 37 & 48.0 & $40000-50000$ & 4 & 5.2 \\
\hline Master and Above & 22 & 28.6 & 50000 and Above & 3 & 3.9 \\
\hline
\end{tabular}

Source: Field survey, 2016.

\section{Job Satisfaction : Factors Ranking}

Cooperative managers were requested to rank the factors of job satisfaction according to their satisfaction level. For this purpose, 9 factors were provided to measure their job satisfaction were provided. For 7 of the 9 factors, more than 50 percent of the responses could be put under the category of "satisfied". They noted "communication with the board" (83.1 
percent), "nature of the work" (80.5 percent), "business relation with the board" (80.5 percent) and "reward and punishment system" (70.1 percent) as most satisfying factors of their job (Table 2).

Table 2: Ranking of Managers Responses

\begin{tabular}{|c|c|c|c|c|c|c|c|c|}
\hline \multirow{2}{*}{$\begin{array}{l}\text { Factors Related to } \\
\text { Job Satisfaction }\end{array}$} & \multirow{2}{*}{$\mathrm{n}$} & \multicolumn{5}{|c|}{${ }^{\circ}$ Response Ranking } & \multirow{2}{*}{ 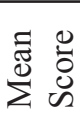 } & \multirow{2}{*}{ 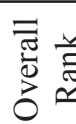 } \\
\hline & & 1 & 2 & 3 & 4 & 5 & & \\
\hline a. Job security & $\begin{array}{c}77 \\
(100)\end{array}$ & $\begin{array}{c}19 \\
(24.7)\end{array}$ & $\begin{array}{c}40 \\
(51.9)\end{array}$ & $\begin{array}{c}8 \\
(10.4) \\
\end{array}$ & $\begin{array}{c}9 \\
(11.7)\end{array}$ & $\begin{array}{c}1 \\
(1.3)\end{array}$ & 2.13 & 2.5 \\
\hline $\begin{array}{l}\text { b. Reward and } \\
\text { punishment } \\
\text { system }\end{array}$ & $\begin{array}{c}77 \\
(100)\end{array}$ & $\begin{array}{c}10 \\
(13.0)\end{array}$ & $\begin{array}{c}44 \\
(57.1)\end{array}$ & $\begin{array}{c}12 \\
(15.6)\end{array}$ & $\begin{array}{c}6 \\
(7.8)\end{array}$ & $\begin{array}{c}5 \\
(6.5)\end{array}$ & 2.38 & 5 \\
\hline $\begin{array}{l}\text { c. Compensation and } \\
\text { benefit system }\end{array}$ & $\begin{array}{c}77 \\
(100)\end{array}$ & $\begin{array}{c}6 \\
(7.8)\end{array}$ & $\begin{array}{c}36 \\
(46.7)\end{array}$ & $\begin{array}{c}20 \\
(26.0)\end{array}$ & $\begin{array}{c}8 \\
(10.4)\end{array}$ & $\begin{array}{c}7 \\
(9.1)\end{array}$ & 2.66 & 8 \\
\hline $\begin{array}{l}\text { d. Communication } \\
\text { with the board }\end{array}$ & $\begin{array}{c}77 \\
(100)\end{array}$ & $\begin{array}{c}21 \\
(27.3)\end{array}$ & $\begin{array}{c}43 \\
(55.8)\end{array}$ & $\begin{array}{c}7 \\
(9.1)\end{array}$ & $\begin{array}{c}3 \\
(3.9)\end{array}$ & $\begin{array}{c}3 \\
(3.9)\end{array}$ & 2.01 & 1 \\
\hline $\begin{array}{l}\text { e. Nature of the } \\
\text { work }\end{array}$ & $\begin{array}{c}77 \\
(100)\end{array}$ & $\begin{array}{c}16 \\
(20.8)\end{array}$ & $\begin{array}{c}46 \\
(59.7)\end{array}$ & $\begin{array}{c}7 \\
(9.1)\end{array}$ & $\begin{array}{c}5 \\
(6.5)\end{array}$ & $\begin{array}{c}3 \\
(3.9)\end{array}$ & 2.13 & 2.5 \\
\hline $\begin{array}{l}\text { f. Current } \\
\text { remuneration } \\
\text { system }\end{array}$ & $\begin{array}{c}77 \\
(100)\end{array}$ & $\begin{array}{c}8 \\
(10.4)\end{array}$ & $\begin{array}{c}40 \\
(51.9)\end{array}$ & $\begin{array}{c}13 \\
(16.9)\end{array}$ & $\begin{array}{c}14 \\
(18.2)\end{array}$ & $\begin{array}{c}2 \\
(2.6)\end{array}$ & 2.51 & 7 \\
\hline $\begin{array}{l}\text { g. Career } \\
\text { development } \\
\text { opportunities }\end{array}$ & $\begin{array}{c}77 \\
(100)\end{array}$ & $\begin{array}{c}7 \\
(9.1)\end{array}$ & $\begin{array}{c}29 \\
(37.6)\end{array}$ & $\begin{array}{c}20 \\
(26.0)\end{array}$ & $\begin{array}{c}17 \\
(22.1)\end{array}$ & $\begin{array}{c}4 \\
(5.2)\end{array}$ & 2.77 & 9 \\
\hline $\begin{array}{l}\text { h. Nature of } \\
\text { supervision }\end{array}$ & $\begin{array}{c}77 \\
(100)\end{array}$ & $\begin{array}{c}13 \\
(16.9)\end{array}$ & $\begin{array}{c}40 \\
(51.9)\end{array}$ & $\begin{array}{c}10 \\
(13.0)\end{array}$ & $\begin{array}{c}8 \\
(10.4)\end{array}$ & $\begin{array}{c}6 \\
(7.8)\end{array}$ & 2.40 & 6 \\
\hline $\begin{array}{l}\text { i. Business relation } \\
\text { with the board }\end{array}$ & $\begin{array}{c}77 \\
(100)\end{array}$ & $\begin{array}{c}18 \\
(23.4)\end{array}$ & $\begin{array}{c}44 \\
(57.1)\end{array}$ & $\begin{array}{c}6 \\
(7.8)\end{array}$ & $\begin{array}{c}3 \\
(3.9)\end{array}$ & $\begin{array}{c}6 \\
(7.8)\end{array}$ & 2.16 & 4 \\
\hline
\end{tabular}

Source: Field survey, 2016.

Note (a): The response rankings are defined as follows: $1=$ highly satisfied, $2=$ satisfied, $3=$ not satisfied, $4=$ dissatisfied and $5=$ completely dissatisfied.

Note (b): Figures in parentheses indicate percentage over total responses.

Note (c): Welss, Dawis, England, \& Lofquist (1967) provided the twenty sample items in the Minnesota satisfaction questionnaire. Out of them, only nine items were appropriate in the context of Nepalese cooperative societies. 
As regards to the overall ranking of the factors of job satisfaction, the majority of the respondents gave first priority to "communication with the board", the equal (second and third) to "job security" and "nature of the work", the fourth priority to "business relation with the board", the fifth priority to "reward and punishment system", the sixth priority to "nature of supervision", the seventh priority to "current remuneration system", the eighth priority to "compensation and benefit system" and the last priority to "career development opportunities" (Table 2).

\section{Overall Job Satisfaction}

All the job satisfaction variables - job security, reward and punishment system, compensation and benefit system, communication with the board, nature of the work, current remuneration system, career development opportunities, nature of supervision and business relation with the board-have been included to measure the overall job satisfaction level of managers. Then, median is computed to find the percent of job satisfaction. Job satisfaction is qualitative dimension. So, median value has been used to find out the overall job satisfaction level. The final outcome shows, 44.2 percent of the managers are satisfied and 55.8 percent are dissatisfied (Table 3).

Table 3: Managers Overall Job Satisfaction

\begin{tabular}{|l|r|r|}
\hline Response & No & Percent \\
\hline Satisfied & 34 & 44.2 \\
\hline Dissatisfied & 43 & 55.8 \\
\hline Total & 77 & 100.0 \\
\hline
\end{tabular}

Source: Field survey, 2016.

\section{Gender and Job Satisfaction}

The majority of the respondents (77.9 percent) were male and only 22.1 percent were female.(Table 1). In terms of the gender of respondents, there was a shift from the male to female, on the overall job satisfactions, i.e. $51.5 \%$ (1- 0.485$)$ of the females were dissatisfied. It means females were more dissatisfied than male. The $\mathrm{p}$ value $(0.005$, which was less than five percent) has indicated that the overall job satisfaction and gender were significantly related (Table 4). 
Table 4: Regression Equation of Overall Job Satisfaction on the basis of Respondents Gender

\begin{tabular}{|l|l|r|r|r|r|r|}
\hline \multicolumn{2}{|l|}{ Model } & \multicolumn{2}{|c|}{$\begin{array}{c}\text { Unstandardized } \\
\text { Coefficients }\end{array}$} & $\begin{array}{c}\text { Standardized } \\
\text { Coefficients }\end{array}$ & t & Sig. \\
\cline { 2 - 4 } \multicolumn{2}{|l|}{} & B & Std. Error & Beta & & \\
\hline \multirow{2}{*}{1} & (Constant) & 21.735 & 1.745 & -.041 & 12.454 & .000 \\
\cline { 2 - 3 } \cline { 6 - 7 } & $\begin{array}{l}\text { Gender of } \\
\text { Respondents }\end{array}$ & -.485 & 1.354 & & -.359 & .005 \\
\hline
\end{tabular}

Source: Field survey, 2016.

Note: Dependent Variable: Overall Job Satisfaction

\section{Experience and Job Satisfaction}

As regards to the total years of service in the current cooperatives, 50.6 percent of the managers covered by this study are with less than 5 years of job experience, 37.7 percent are with 5 to 10 years of experience, 6.5 percent have experience of 15 years and above, and the rest are with 10 to 15 years of job experience. The average service year of the managers is 5.43 years (Table 1). Regression equation of overall job satisfaction on job experience shows the negative association between job experience and overall job satisfaction. If there is one unit increase in experience overall satisfaction will be decreased by 0.028 units. But the $p$ value 0.001 (which is less than five percent) shows that there is significant association between overall job satisfaction and job experience (Table 5).

Table 5: Regression Equation of Overall Job Satisfaction on the basis of Job Experiences of Manager

\begin{tabular}{|l|l|r|r|r|r|r|}
\hline \multirow{2}{*}{ Model } & \multicolumn{2}{|c|}{$\begin{array}{c}\text { Unstandardized } \\
\text { Coefficients }\end{array}$} & $\begin{array}{c}\text { Standardized } \\
\text { Coefficients }\end{array}$ & t & \multicolumn{1}{c|}{ Sig. } \\
\cline { 2 - 4 } \multicolumn{2}{|c|}{} & \multicolumn{1}{|c|}{ B } & Std. Error & Beta & & \\
\hline \multirow{2}{*}{1} & (Constant) & 21.296 & .909 & & 23.419 & .000 \\
\cline { 2 - 3 } \cline { 6 - 7 } & $\begin{array}{l}\text { Job } \\
\text { Experiences }\end{array}$ & -.028 & .132 & -.025 & -.214 & .001 \\
\hline
\end{tabular}

Source: Field survey, 2016.

Note: Dependent Variable: Overall Job Satisfaction 


\section{Remuneration and Job Satisfaction}

As far as the remuneration of the respondents is concerned, according to Table 9, 39 percent of the managers receive monthly remuneration from Rs 20000 to Rs 30000 at present. Similarly, 18.2 percent managers receive monthly remuneration in both ranges as below Rs 10000 and Rs 10000 to Rs 20000. The average salary of the managers is Rs 23708.44 (Table 1). Regression equation of the overall job satisfaction on remuneration of the manager shows positive association between remuneration and overall job satisfaction. If there is one unit increase in remuneration of the managers, overall job satisfaction will be increased by 0.000106 . But the $p$ value 0.002 (which is less than five percent) indicates that there is significant association between managers' remuneration and overall job satisfaction (Table 6).

Table 6: Regression Equation of Remuneration and Job Satisfaction

\begin{tabular}{|c|c|c|c|c|c|}
\hline \multirow[t]{2}{*}{ Model } & \multicolumn{2}{|c|}{$\begin{array}{l}\text { Unstandardized } \\
\text { Coefficients }\end{array}$} & \multirow{2}{*}{$\begin{array}{c}\begin{array}{c}\text { Standardized } \\
\text { Coefficients }\end{array} \\
\text { Beta }\end{array}$} & \multirow[t]{2}{*}{$\mathbf{t}$} & \multirow[t]{2}{*}{ Sig. } \\
\hline & B & Std. Error & & & \\
\hline (Constant) & 23.661 & .947 & \multirow[b]{2}{*}{.347} & 24.997 & .000 \\
\hline \begin{tabular}{|l|l|} 
& $\begin{array}{l}\text { Remuneration } \\
\text { of Managers }\end{array}$ \\
\end{tabular} & 0.000106 & .000 & & -3.203 & .002 \\
\hline
\end{tabular}

Source: Field survey, 2016.

Note: Dependent Variable: Overall Job Satisfactions

\section{CONCLUSION}

As regards to the general background, the result had indicated that most of the managers were male. Regarding the age of the managers, nearly two-third were of below 40 years. It implies that majority of the managers of the cooperatives were the young and energetic. About marital status, most of the managers were married. Similarly, most of the managers were from Brahmin/Chhetry and Hindu religion. Regarding the education level of the managers, nearly three-fourth of them were bachelor degree and master and above; the majority were from management background. Most of the managers had job experiences of less than 10 years. It was found that cooperative managers were well educated, matured and competent in their field. The managers from female and ethnic group were less than the male and Brahmin/Chhetry respectively.

To come to the conclusion about the overall job satisfaction of the managers, using median value, it was found that most of the managers 
were dissatisfied. And, regarding the overall rank for related factors of job satisfaction, it was found that the first priority goes to the "communication with the board" as highly satisfying factor and the last priority to career development opportunities as completely dissatisfying factor of their job satisfaction. In case of sex wise analysis, females were more dissatisfied than males. The result also had indicated that when the job experience was increased, the satisfaction level was decreased. The regression equation of overall job satisfaction on remuneration of the manager was seemed to be the positive relation between remuneration and the overall job satisfaction.

\section{ACKNOWLEDGEMENTS}

This article is an outcome of mini research report submitted to the Center for Research, Rector's Office, Tribhuvan University, Kirtipur. I highly acknowledge Center for Research and all those patient managers/ office heads of sample cooperatives of Pokhara, for providing me necessary data and information.

\section{REFERENCES}

Atreya, B. (2014). Engaging and inspiring employees. In S. Paudel (Ed.), Nepal Rastra Bank Samachar: Nepal Rastra Bank 59th Anniversary Special Issue (4-8). Kathmandu: Nepal Rastra Bank.

Chadi, A., \& Hetschko, C. (2014). The magic of the new: How job changes affect job satisfaction. IAAEU Discussion Paper Series in Economics No. 05/2014.

Cooperative Training and Division Office. (2015). Cooperatives in Kaski: An outlook. Pokhara: Author.

Frederick, D. A. (1997). An Introduction to cooperatives. United States: Department of Agriculture.

Grund, C., \& Rubin, M. (2016). Social comparisons of wage increase and job satisfaction. Retrieved from http://ftp.iza.org/dp10038.pdf

Likert, R. (1932). A technique for the measurement of attitudes. Archives of psychology. Retrieved from https://legacy.voteview.com/pdf/ Likert_1932.pdf

Moorhead, G., \& Griffin, R. W. (2000). Organizational behavior (3rd ed.). Mumbai: Jaico Publishing House.

Pradhan, R. S. (2003). Research in Nepalese finance. Kathmandu: Buddha Academic Publishers and Distributors. 
Pravin, M. M., \& Kabir, M. M. N. (2011). Factors affecting employee job satisfaction of pharmaceutical sector. Austrian Journal of Business and Management Research, 1(9), 113-123.

Robbins, S. P., Judge, T. A., \& Vohra, N. (2013). Organizational behavior ( $5^{\text {th }}$ ed.). Delhi: Pearson.

Saari, L. M., \& Judge, T. A. (2004). Employee attitudes and job satisfaction. Human resource management. Retrieved form 43(4), 395-407. doi:10.1002/hrm.20032

Shrestha, P. (2015). Organizational behavior. Kathmandu: Samjhana Publication.

Sukriket, P. (2018). The relationship between job satisfaction and turnover intention of Thai software programmers in Bangkok, Thailand. $A U$ Journal of Management, 12(2), 42-52.

Tella, A., Ayeni, C. O., \& Popoola, S. O. (2007). Work motivation, job satisfaction, and organisational commitment of library personnel in academic and research libraries in Oyo State, Nigeria. Library Philosophy and Practice, 9(2), 1-13.

Thakuri, C. B. (2010). An anatomy of cooperative movement in Nepal. Kathmandu: Upkar Prakashan.

United Nations. (2009). Report of the secretary general: Cooperatives in social development. Retrieved from http://www.copac.coop/ publications/ un/a64132e.pdf

Welss, D. J., Dawis, R. V., England, G. W., \& Lofquist, L. H. (1967). Manual for the Minnesota satisfaction questionnaire. University of Minnesota. Retrieved from http://vpr.psych.umn.edu/sites/g/files/ pua2236/f/monograph_xxii_-_manual_for_the_mn_satisfaction_ questionnaire.pdf

Yousef, D. A. (2000). Organizational commitment: A mediator of the relationships of leadership behavior with job satisfaction and performance in non-western country. Journal of Managerial Psychology, 15(1), 6-24. 